\title{
Valproic acid suppresses interleukin-1 $\beta$-induced microsomal prostaglandin E2 Synthase-1 expression in chondrocytes
}

\author{
N Zayed ${ }^{*}$, N Chabane, J Martel-Pelletier, J P Pelletier, N Duval, H Fahmi \\ From 5th European Workshop on Immune-Mediated Inflammatory Diseases \\ Sitges-Barcelona, Spain. 1-3 December 2010
}

\section{Introduction}

Microsomal prostaglandin E2 Synthase (mPGES)-1 catalyzes the terminal step in the biosynthesis of $\mathrm{PGE}_{2}$. Early growth response factor-1 (Egr-1) is a key transcription factor in the regulation of mPGES-1. In the present study we examined the effects of valproic acid (VA), a histone deacetylase (HDAC) inhibitor, on interleukin (IL)-1 $\beta$-induced mPGES-1-expression in human chondrocytes.

\section{Methods}

Chondrocytes were stimulated with IL-1 in the absence or presence of VA, and the level of mPGES-1 protein and mRNA expression were evaluated using Western blotting and real-time reverse-transcription polymerase chain reaction, respectively. The mPGES-1 promoter activity was analyzed in transient transfection experiments. Egr-1 recruitment to the mPGES-1 promoter were evaluated using chromatin immunoprecipitation (ChIP) assays.

\section{Results}

VA dose-dependently suppressed IL-1 $\beta$-induced mPGES-1 protein and mRNA expression as well as its promoter activation. Treatment with VA did not alter IL-1-induced Egr-1 expression, nor its recruitment to the mPGES-1 promoter, but prevented its transcriptional activity.

Osteoarthritis Research Unit, Research Centre of the University of Montreal Hospital Center (CR-CHUM), Notre-Dame Hospital, and Dept. of Medicine,

University of Montreal, Montreal, Quebec, Canada

\section{Conclusion}

Our study demonstrates that VA inhibits IL-1-induced mPGES-1 expression in chondrocytes. The suppressive effect of VA was not due to reduced expression or recruitment of Egr-1 to the mPGES-1 promoter.

Published: 25 November 2010

doi:10.1186/1479-5876-8-S1-P60

Cite this article as: Zayed et al:: Valproic acid suppresses interleukin-1 $\beta$ induced microsomal prostaglandin E2 Synthase-1 expression in chondrocytes. Journal of Translational Medicine 2010 8(Suppl 1):P60.
Submit your next manuscript to BioMed Central and take full advantage of:

- Convenient online submission

- Thorough peer review

- No space constraints or color figure charges

- Immediate publication on acceptance

- Inclusion in PubMed, CAS, Scopus and Google Scholar

- Research which is freely available for redistribution

\section{() Biomed Central}

